DOI: $10.19195 / 0137-1134.113 .2$

\author{
JUSTYNA CZERNIAK-SWĘDZIOŁ \\ Uniwersytet Jagielloński
}

\title{
ROLA PRACODAWCY W REALIZOWANIU UPRAWNIEŃ PRACOWNIKÓW ZWIĄZANYCH Z RODZICIELSTWEM
}

\begin{abstract}
Abstrakt: W ciągu ostatnich dziesięciu lat kodeks pracy znacząco zwiększył uprawnienia pracowników związane z rodzicielstwem, a co za tym idzie rola pracodawcy w zakresie ich realizacji także zmieniła się zasadniczo.

Pracodawca pozostaje zobowiązany do wypełniania kodeksowych podstawowych praw pracownika jako rodzica. Jednakże polski ustawodawca zdecydowanie za bardzo obciąża podmiot zatrudniający rolą jedynego wykonawcy tych ogólnych zasad społecznych związanych z ochroną macierzyństwa i rodziny, co doprowadza do wyraźnego zachwiania w realizacji konstytucyjnych obowiązków państwa wobec swoich obywateli.

Przyglądając się poszczególnym etapom zatrudnienia: od okresu ciąży, w którym ochrona ma szczególnie mocny wydźwięk, przez obowiązek realizacji prawa do urlopów rodzicielskich i zobowiązania nałożone na pracodawcę do zatrudnienia pracownika po wykorzystaniu urlopów, na ochronie w okresie sprawowania opieki nad dzieckiem kończąc, widać wyraźnie znaczące ograniczenia i obciążenia dla pracodawcy. Obciążenia nakładane na konkretnego pracodawcę często pozostają całkowicie nieproporcjonalne w stosunku do jego możliwości.

Pracodawca ponosi koszty polityki społecznej, które powinny być realizowane przez państwo, a więc pełni funkcję gwaranta w zabezpieczaniu interesów społecznych. Rozwiązania przyjęte przez polskiego ustawodawcę stoją w wyraźnej opozycji do regulacji prawa międzynarodowego.

Spoczywające aktualnie na pracodawcy obciążenia wynikające z przepisów kodeksu pracy mogłyby być realizowane w znacznym stopniu przez odpowiednie publiczne systemy ubezpieczeniowe. De lege ferenda obowiązek ochrony macierzyństwa oraz rodziny jako konstytucyjny obowiązek społeczny winien być realizowany wspólnie przez państwo i pracodawcę. De lege lata wyraźnie widoczna w obowiązujących przepisach nieproporcjonalność znacząco ogranicza zasadę wolności gospodarczej oraz własności pracodawcy w szczególności w stosunku do małych przedsiębiorców.
\end{abstract}

Słowa kluczowe: pracodawca, uprawnienia rodzicielskie

\section{WSTĘP}

W ciągu ostatnich dziesięciu lat kodeks pracy znacząco zwiększył uprawnienia pracowników związane z rodzicielstwem i tym samym zasadniczo zmieniła się rola pracodawcy w zakresie ich realizacji. Niewątpliwie jednym z jego pod- 
stawowych obowiązków jest dbałość o dobro pracownika, co oznacza powinność dostarczania pracownikowi informacji i dokumentów istotnych z punktu widzenia uprawnień mających swoje źródło w stosunku pracy ${ }^{1}$. Zgodnie z zasadą wyrażoną w art. 94 pkt 1 k.p. pracodawca pozostaje w bezwzględnym obowiązku zaznajamiania pracowników z ich podstawowymi uprawnieniami, w tym uprawnieniami rodzicielskim. Pracodawca ma zatem zapewnić każdemu pracownikowi-rodzicowi możliwości zrealizowania uprawnień związanych z tą znaczącą rolą społeczną, jaką jest rodzicielstwo. Zresztą jak wynika z orzecznictwa Sądu Najwyższego², pracownik może dochodzić przed sądem pracy nakazania udzielenia przez pracodawcę informacji mających istotne znaczenie dla jego sytuacji pracowniczej.

Przyglądając się pracodawcy jako podmiotowi wypełniającemu podstawowe prawa pracownika-rodzica, należy dokonać wyraźnego podziału i rozróżnienia na te bezpośrednio związane z realizacją funkcji ochronnej oraz te związane z dostosowywaniem i organizacją procesu pracy. Niniejszy artykuł będzie nie tylko spojrzeniem na to, jak pracodawca, zgodnie z kodeksem pracy, winien realizować swoje podstawowe obowiązki względem pracownika-rodzica, lecz także próbą odpowiedzi na pytanie, czy ustawodawca za bardzo nie obciążył pracodawcy obowiązkiem jedynego wykonawcy ogólnych zasad społecznych związanych z ochroną macierzyństwa i rodziny, co doprowadza do wyraźnego zachwiania w realizacji konstytucyjnych obowiązków państwa wobec swoich obywateli. I czy takie przerzucenie obowiązków nie doprowadza w istocie do obawy i zniechęcenia pracodawcy przed zatrudnieniem kobiet czy też pracowników mających już dzieci. Analiza poszczególnych etapów zatrudnienia od okresu ciąży, w którym ochrona ma szczególnie mocny wydźwięk, przez obowiązek realizacji prawa do urlopów rodzicielskich i zobowiązanie nałożone na pracodawcę do zatrudnienia po ich wykorzystaniu, po ochronę w okresie sprawowania opieki nad dzieckiem, pozwoli odpowiedzieć na postawione pytania i skłoni do sformułowania wniosków de lege lata i de lege ferenda.

\section{REALIZACJA FUNKCJI OCHRONNEJ Z TYTUŁU UPRAWNIEŃ RODZICIELSKICH}

A) GWARANCJE PRACODAWCY W ZAPEWNIENIU STABILNOŚCI ZATRUDNIENIA KOBIETY W CIĄŻY ORAZ PRACOWNIKA-RODZICA KORZYSTAJĄCEGO

\section{Z URLOPU MACIERZYŃSKIEGO}

Rozważania na temat roli i miejsca pracodawcy w realizacji funkcji ochronnej przy uprawnieniach rodzicielskich rozpocząć należy od omówienia gwarancji, które od ustawodawcy otrzymali: kobieta będąca w ciąży i jednocześnie pozostająca

1 D. Dörre-Kolasa, Komentarz do art. 94 k.p., [w:] Kodeks pracy. Komentarz, red. A. Sobczyk, Warszawa 2017, s. 455.

${ }^{2}$ Wyrok SN z dnia 16 września 1999 r., I PKN 331/99, OSNAPiUS 2001, nr 9, poz. 314. 
W zatrudnieniu oraz pracownicy-rodzice uprawnieni do urlopu macierzyńskiego. Przedmiotem dokonywanej przeze mnie oceny będzie przede wszystkim regulacja art. 177 k.p., sprowadzona do dwóch instytucji — zakazu wypowiadania/rozwiązania przez pracodawcę umowy w okresie ciąży/urlopu macierzyńskiego oraz przedłużania z mocy prawa niektórych terminowych umów o pracę do dnia porodu.

Zgodnie z dyspozycją art. $177 \S 1$ k.p. zakaz wypowiadania i rozwiązywania dotyczy wszystkich rodzajów umów o pracę, z wyjątkiem umowy w okresie próbnym nieprzekraczającym jednego miesiąca ${ }^{3}$. Nie podlega żadnej dyskusji, że fundamentem ochrony macierzyństwa jest przede wszystkim szczególna ochrona stabilności zatrudnienia związana z ciążą i rodzicielstwem, którą wskazany przepis w pełni realizuje. Wprowadzona konstrukcja znacząco ogranicza, wręcz wyłącza swobodę działania pracodawcy w tym zakresie, a jednocześnie daje pracownikowi pełne prawo do zakończenia stosunku pracy z pracodawcą. Przepis ten nie dotyczy także rozwiązania umowy o pracę na mocy porozumienia stron. Nie należy jednak zapominać o orzeczeniach Sądu Najwyższego dopuszczających możliwość uchylenia się od oświadczenia woli złożonego przez pracownicę, która w chwili zawierania porozumienia o rozwiązaniu umowy o pracę nie wiedziała, że jest w ciąży ${ }^{4}$. Podobną linię orzeczniczą można zauważyć przy wypowiedzeniu umowy o pracę przez pracownicę, która nie wiedząc, że jest w ciąży, złożyła oświadczenie woli zmierzające do rozwiązania umowy o pracę ${ }^{5}$.

Realizacja przez pracodawcę obowiązku ochronnego polega nie tylko na tym, że nie może on wypowiedzieć umowy o pracę w okresie, w którym kobieta jest w ciąży, lecz także na tym, że zajście w ciążę w okresie wypowiedzenia czyni wcześniej złożone przez pracodawcę wypowiedzenie wadliwym i wówczas musi on przywrócić pracownicę do pracy, wypełniając jednocześnie, w obu przypadkach, niezwykle ważną, wyrażoną w konstytucji zasadę społeczną — ochronę macierzyństwa. Należałoby więc zadać niezwykle istotne pytanie, a mianowicie: czy przyjęty przez ustawodawcę model ochrony pracownika-rodzica jest właściwy, zważywszy na podmiot obciążony jego wykonaniem, czyli pracodawcę? Zgodnie $\mathrm{z}$ art. 18 Konstytucji $\mathrm{RP}^{6}$ ochrona rodziny, macierzyństwa i rodzicielstwa jest obowiązkiem społecznym. Nakaz zapewnienia wskazanym wartościom

3 W literaturze zaprezentowany został pogląd, że ochrona powinna występować niezależnie od długości faktycznego zatrudnienia, zob. T. Liszcz, Ochrona pracy kobiet i pracowników wychowujacych dzieci - propozycje zmian, PiZS 1989, z. 1, s. 22-28.

4 Zob. wyrok SN z dnia 19 marca 2002 r., I PKN 156/01, OSNP 2004, nr 5, poz. 78; krytyki tego orzeczenia oraz orzeczenia dotyczącego wadliwości rozwiązania umowy o pracę mimo niewadliwości wypowiedzenia, zob. wyrok SN z dnia 2 czerwca 1995 r., I PRN 23/95, OSNP 1995, nr 22, poz. 276, dokonał A. Sobczyk, Komentarz do art. 177 k.p., [w:] Kodeks pracy. Komentarz, s. 713; idem, Prawo pracy $w$ świetle Konstytucji RP, t. 2. Wybrane problemy i instytucje prawa pracy a ochrona konstytucyjnych praw i wolności człowieka, Warszawa 2013, s. 194-195; zob. także wyrok SN z dnia 25 kwietnia 2012 r., II PK 209/11, M.P.Pr. 2012, nr 9, s. 450.

5 Por. wyrok SN z dnia 11 czerwca 2003 r., I PK 206/02, OSNP 2004, nr 16, poz. 278.

${ }^{6}$ Konstytucja Rzeczypospolitej Polskiej z dnia 2 kwietnia 1997 r. (Dz.U. poz. 483, ze zm.). 
nie tylko ochrony, lecz także opieki obciąża państwo. Zarówno małżeństwo, jak i rodzina są bowiem elementami ładu społecznego i porządku prawnego. Także z art. 71 Konstytucji wynika gwarancja prawnej ochrony macierzyństwa. Treść art. 71 ust. 1 zd. 1 zawiera zasady opieki i ochrony państwa nad rodziną, wyrażonej w art. 18 Konstytucji. Natomiast art. 71 ust. 2 Konstytucji jest uszczegółowieniem ustrojowej zasady ochrony macierzyństwa ${ }^{7}$. Czy można zatem nałożyć obowiązek ochrony i opieki tych wartości na konkretny, indywidualny podmiot zatrudniający? Zdaniem A. Sobczyka ${ }^{8}$ oczywiście jedno nie wyklucza drugiego w tym znaczeniu, iż obowiązek ten może być realizowany zarówno przez państwo, jak i pojedynczego pracodawcę, ale — jak podkreśla autor — przy zachowaniu właściwej proporcji obciążenia w jego wykonaniu. Tymczasem z brzmienia obowiązujących przepisów kodeksu pracy wywodzony jest obowiązek ochrony spoczywający wyłącznie na pracodawcy. Mało tego, obciążenie konkretnego pracodawcy może być całkowicie nieproporcjonalne do jego możliwości i podzielam pogląd, że takie rozwiązane jest absolutnie nie do przyjęcia. Ustawodawca nie uwzględnia przy tym, czy konkretnego pracodawcę w ogóle stać na realizację owego celu społecznego. Przecież pracodawca zobowiązany pozostaje do ponoszenia konkretnych kosztów związanych z zatrudnianiem kobiety w ciąży i to bez możliwości zwolnienia jej z pracy oraz bez możliwości obniżenia jej wynagrodzenia i to nie tylko w sytuacji, kiedy może nie mieć pracy dla takiej kobiety, nie mieć zapotrzebowania na taką pracę, ale również w sytuacji, kiedy taka praca, siłą rzeczy, staje się mniej wydajna. Zgodnie z brzmieniem art. 179 k.p., który odnosi się do ochrony życia i zdrowia zarówno kobiety, płodu, jak i dziecka, na pracodawcę nałożony zostaje bezwzględny obowiązek przeniesienia pracownicy do innej pracy względnie zwolnienia jej na czas niezbędny z obowiązku świadczenia pracy, niezależnie od wiążacych się z tym trudnościami natury organizacyjnej i kosztami. Instytucja przeniesienia, o której mowa $\mathrm{w}$ tym przepisie, stanowi ingerencję pracodawcy w treść umowy o pracę, który bez zgody pracownicy powierza jej inną pracę. W tym przypadku nie znajdzie zastosowania art. 42 k.p. i dlatego też kryterium kwalifikacji pracownicy nie jest w ogóle uwzględniane. Pracodawca, stosując to rozwiązanie, nie może naruszyć zakazu dyskryminacji ani też przekroczyć zasad chroniących godność takiej pracownicy. Oczywiście podstawowym celem przeniesienia jest uniknięcie sytuacji, w której pracodawca będzie z powodów socjalnych ponosił koszty wynagrodzenia, bez świadczenia wzajemnego, ale nie zawsze ten podstawowy cel pracodawca może osiągnąć. W tej sytuacji, co do zasady, wypłata wynagrodzenia również nie może zostać zmieniona, nawet gdy praca na nowym stanowisku jest mniej wartościowa. Obniżone wynagrodzenie zostaje bowiem zrekompensowane stosownym dodatkiem wyrównawczym, który nie jest wynagrodzeniem, ale świadczeniem o charak-

7 Zob. S. Stecko, Konstytucyjna zasada ochrony macierzyństwa i rodzicielstwa oraz wynikajace z niej uprawnienia kobiet-pracownic w zwiazku z urodzeniem dziecka, „Przegląd Prawa Publicznego" 2017, nr 5, s. 59-68.

8 A. Sobczyk, Prawo pracy w świetle Konstytucji RP, t. 2, s. 195. 
terze socjalnym ${ }^{9}$. Jego podstawowym celem jest zapewnienie pracownicy dochodów w nieobniżonej wysokości niezależnie od wartości ekonomicznej świadczonej przez nią pracy. Zgodnie z linią orzeczniczą zmniejszona wydajność pracy na nowym stanowisku nie może zaważyć ujemnie na wysokości należnego pracownicy w ciąży dodatku wyrównawczego, ze względu na konieczność zabezpieczenia interesu społecznego przez zagwarantowanie matce warunków zdrowotnych, a dziecku warunków właściwego rozwoju ${ }^{10}$. Jeżeli stan ciąży uniemożliwia pracownicy osiąganie wyników uzasadniających utrzymanie wcześniejszych dochodów, to i tak zdaniem Sądu Najwyższego ${ }^{11}$ — należy się jej dodatek wyrównawczy. Pracownicy-lekarzowi przysługuje dodatek wyrównawczy przewidziany w art. 179 § 2 k.p., jeżeli poprzednio pełniła dyżury zakładowe, za które otrzymywała dodatkowe wynagrodzenie, a ze względu na ciążę nie może ich pełnić ${ }^{12}$. Również w przypadku zwolnienia z obowiązku świadczenia pracy pracownica, mimo że zachowuje prawo do dotychczasowego wynagrodzenia, w istocie otrzymuje nie wynagrodzenie, lecz stosowne świadczenie odpowiadające jego wysokości. Ze względu na brak cechy wzajemności przy wypłacie tego świadczenia pełni ono - podobnie jak dodatek — funkcję socjalną, która spoczywa na pracodawcy i to bez rozróżnienia na jego wielkość rozumianą przez siłę gospodarczą ${ }^{13}$.

Konkludując, przepisy kodeksu pracy w obecnym kształcie obciążają pracodawcę kosztami polityki społecznej, które powinno realizować państwo. Tym samym pracodawca jest gwarantem zaspokojenia interesów społecznych. Państwo przez ustawodawcę nakazuje pracodawcy zapewnić „byt zawodowy” kobiecie w ciąży bez względu na związane z tym koszty i bez względu na to, czy można lub też nie można uzyskać do takiej pracownicy świadczenie wzajemne w postaci wykonywania pracy ${ }^{14}$. Rozwiązania przyjęte przez polskiego ustawodawcę stoją w wyraźnej opozycji do regulacji prawa międzynarodowego, jasno wskazującego na wspólny obowiązek w zapewnieniu pracownicy ochrony podczas ciąży oraz na gwarancję zatrudnienia dla pracownicy powracającej z urlopu macierzyńskiego na tym samym lub równorzędnym stanowisku przy dotychczasowym wynagrodzeniu $^{15}$ i ochrony rodziny pracownika jako naturalnej i podstawowej komórce społeczeństwa ${ }^{16}$.

9 A. Sobczyk, [w:] Kodeks pracy. Komentarz, s. 720.

10 Zob. wyrok SN z dnia 5 maja 1976 r., I PRN 32/76, LEX 14309; wyrok SN z dnia 5 maja 1976 r., I PRN 27/76, OSP 1977, nr 6, poz. 101.

11 Por. uchwała SN (7) z dnia 15 marca 1979 r., V PZP 13/78, OSNCP 1979, nr 6, poz. 110. Zob. także uchwałę SN z dnia 29 czerwca 1979 r., LEX 14501.

12 Uchwała SN (7) z dnia 28 kwietnia 1994 r., I PZP 6/94, OSNP 1994, nr 8, poz. 125.

13 A. Sobczyk, Komenatrz do art. 179 k.p., [w:] Kodeks pracy. Komentarz, s. 721.

14 A. Sobczyk, Prawo pracy w świetle Konstytucji RP, t. 2, s. 196.

15 Konwencja MOP nr 183 dotycząca rewizji Konwencji dotyczącej ochrony macierzyństwa (zrewidowanej) z 1952 r., art. 8 ust. 2.

16 Powszechna deklaracja praw człowieka ONZ z 1948 r., art. 16 ust. 3, http://www.unesco. pl/fileadmin/user_upload/pdf/Powszechna_Deklaracja_Praw_Czlowieka.pdf (dostęp 13.08.2018). 
Pracodawca występujący w roli podmiotu zobowiązanego do zatrudniania socjalnego pojawia się również przy przedłużaniu do dnia porodu z mocy prawa terminowej umowy o pracę zawartej z kobietą będącą w ciąży. Sama koncepcja ustawodawcy wydaje się z założenia słuszna i zasługująca na aprobatę, albowiem nadrzędna jest bezpośrednia ochrona interesu ekonomicznego kobiety i pośrednia ochrona dziecka, ale ponownie dochodzi tutaj do zachwiania proporcji w realizacji celów społecznych wyłącznie kosztem podmiotu zatrudniającego. Ustawodawca nie dba o interesy pracodawcy i nie zważa kompletnie na to, że zatrudnienie terminowe mogło mieć przecież dla pracodawcy uzasadnienie głównie ekonomiczne. Bagatelizuje się też sam charakter umowy na okres próbny. Zdaniem A. Sobczyka ${ }^{17}$ kobieta $\mathrm{w}$ okresie próbnym nie powinna być chroniona $\mathrm{w}$ ogóle, co wynika z aksjologicznego celu tej umowy. W opinii tego autora skoro okres próby może dowieść nieprzydatności pracownicy do pracy, to zobowiązanie pracodawcy do zatrudnienia kreuje konstrukcję zatrudnienia wyłącznie o charakterze socjalnym ${ }^{18}$. Pozostaję w przekonaniu, iż takie zapatrywania są zbyt daleko idące i pozbawiające pracownicę w ciąży stosownej ochrony przy odgórnym założeniu jej nieprzydatności do pracy. Pozbawienie kobiety w ciąży ochrony w okresie próby mogłoby prowadzić do znacznych nadużyć ze strony pracodawcy, który wiedząc o ciąży, celowo nie przedłużyłby pracownicy umowy o pracę. I to nie tyle z powodu jej nieprzydatność do pracy, ile z powodu obawy zatrudnienia kobiety, która za chwilę przestanie ją świadczyć i „wypadnie” z zatrudnienia przynajmniej na rok.

Stoję na stanowisku, iż ochrona zatrudnienia wyrażona w art. 177 § 3 k.p. powinna zostać zachowana, ale obowiązek utrzymania takiej kobiety do dnia porodu przeniesiony winien zostać na państwo ${ }^{19}$. Zwracam uwagę, iż stosunkowo niedawno ustawodawca dokonał stosownych zmian w zakresie ochrony trwałości zatrudnienia pracownicy tymczasowej ${ }^{20}$, które też kreują model zatrudnienia socjalnego obarczającego pracodawcę. Dotychczas umowy o pracę na czas określony pracownic tymczasowych nie przedłużały się do dnia porodu ze względu na wyłączone stosowanie do nich art. $177 \S 3$ k.p. Od dnia 1 czerwca 2017 r. pracownica tymczasowa, która ma co najmniej dwumiesięczny okres skierowania do wykony-

17 A. Sobczyk, Prawo pracy w świetle Konstytucji RP, t. 2, s. 197.

18 Ibidem.

19 Por. J. Czerniak-Swędzioł, Zakres uprawnień zwiąanych z rodzicielstwem w przypadku zatrudnienia na podstawie terminowej umowy o prace, [w:] Terminowe umowy o prace, red. M. Mędrala, Warszawa 2017, s. 135 n.; zob. także eadem, Uwagi de lege lata $i$ de lege ferenda w przedmiocie umowy o pracę na zastępstwo, „Studia z Zakresu Prawa Pracy i Polityki Społecznej” 22, 2015, s. 300-303; autorka między innymi poddaje krytyce wyłączenie w stosunku do kobiety w ciąży zatrudnionej na zastępstwo ochrony gwarantowanej art. 177 § 3 k.p.

20 Ustawa z dnia 9 lipca 2003 r. o zatrudnianiu pracowników tymczasowych (tekst jedn. Dz.U.2016.360). 
wania pracy tymczasowej przez daną agencję pracy na podstawie umowy o pracę, korzysta z ochrony polegającej na przedłużeniu umowy o pracę do dnia porodu ${ }^{21}$.

Niechronienie interesów pracodawcy przy zatrudnieniu kobiety w ciąży widoczne jest na gruncie obowiązujących przepisów prawa pracy. Pomijając kwestię przymusu zatrudnienia (co przeczy zasadzie dobrowolności), to realnie pracodawca nie może zwolnić kobiety w ciąży, gdy jej praca jest nieefektywna, wadliwa, mniej wartościowa niż innych pracowników albo gdy jej zachowanie uzasadnia utratę zaufania do pracodawcy, a nawet może generować ryzyko wyrządzenia pracodawcy szkody $^{22}$. W pełni podzielam pogląd A. Sobczyka ${ }^{23}$, że nie może być tu argumentem przemawiającym za stosowaniem takich rozwiązań uzasadnienie, że sytuacja kobiety w ciąży na rynku pracy jest trudna i stąd wynika konieczność objęcia jej ochroną u dotychczasowego pracodawcy ${ }^{24}$. Zdaniem autora owo twierdzenie, choć prawdziwe, oznacza, że ustawodawca nie wierzy w ochronę prawną kobiety w ciąży przez zakaz dyskryminacji na etapie rekrutacji. Kobieta w ciąży powinna być traktowana tak samo jak inni kandydaci do pracy. Niestety, świadomość niemożliwości stworzenia skutecznych mechanizmów ochrony kobiety w ciąży na poziomie możliwości podjęcia zatrudnienia nie pozbawia ustawodawcy złudzeń, do maksimum eksploatującego dotychczasowego pracodawcę, którego pracownica zaszła w ciążę, i nie pozostawiając mu właściwie żadnego wyboru, obarcza obowiązkiem, wręcz przymusem utrzymania takiego zatrudnienia kosztem jego własnych interesów ${ }^{25}$.

\section{B) OBOWIĄZEK PRACODAWCY W PRZEDMIOCIE REALIZACJI PRAWA DO URLOPÓW RODZICIELSKICH}

Obowiązek uwzględnienia wniosku uprawnionego pracownika-rodzica

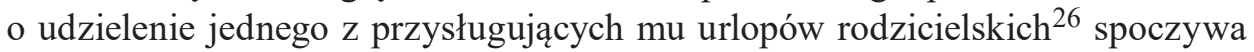
na pracodawcy. Zasada ta zostaje nieco zmodyfikowana w przypadku realizacji prawa do urlopu macierzyńskiego po porodzie, który uruchamiany jest nie w trybie wnioskowym, lecz z mocy prawa z dniem porodu (art. 180 § 3 k.p.). W pozostałych przypadkach jednak pracownik powinien złożyć stosowny wniosek zgodnie z wy-

21 Ustawa z dnia 7 kwietnia 2017 r. (Dz.U.2017.962) zmieniająca ustawę o zatrudnieniu pracowników tymczasowych z dniem 1 czerwca 2017 r., art. 13 ust. 3 zmieniony art. 1 pkt 8 lit. b.

22 A. Sobczyk, [w:] Kodeks pracy. Komentarz, s. 197.

23 A. Sobczyk, Prawo pracy w świetle Konstytucji RP, t. 2, s. 197.

24 Zob. U. Jackowiak, Sytuacja pracownicza kobiet, Gdańsk 1994.

25 A. Sobczyk, Prawo pracy w świetle Konstytucji RP, t. 2, s. 197.

${ }^{26}$ Pod pojęciem urlopów rodzicielskim rozumiem urlop macierzyński, urlop rodzicielski, urlop ojcowski, urlop z tytułu przysposobienia dziecka oraz urlop wychowawczy, zob. także J. Czerniak-Swędzioł, Ewolucja urlopu rodzicielskiego, „Studia z Zakresu Prawa Pracy i Polityki Społecznej" 23, 2016, s. 49-62. 
maganiami stawianymi mu przez ustawodawcę $\mathrm{w}$ rozporządzeniu wykonawczym z 2015 r. ${ }^{27}$ do art. 186 (8a) k.p.

Zgodnie z brzmieniem obowiązujących przepisów (art. 179 (1) § 5 k.p., art. 182 (1d) k.p.) pracodawca pozostaje w obowiązku uwzględnić wnioski urlopowe uprawnionych pracowników-rodziców. Zatem pracownik nie może udać się na zawnioskowany urlop bez zgody pracodawcy. Niemniej jednak ze względu na wartości chronione urlopami rodzicielskimi można przyjąć, że pracodawca, nie reagując, tym samym taką zgodę wydaje ${ }^{28}$. Należy przy tym jednak zaznaczyć, że pracodawca nie może nie udzielić jednego z przysługujących urlopów rodzicielskich, jeżeli pracownik-rodzic zachował wymagany termin, a wniosek urlopowy jest kompletny, i to nawet gdyby skorzystanie z urlopu mogło naruszyć interes gospodarczy pracodawcy. Ochrona wartości stojących za instytucją urlopów rodzicielskich zdecydowanie przewyższa wartości ekonomiczne pracodawcy i jego wolność w prowadzeniu działalności gospodarczej.

Zgodnie z orzeczeniem Trybunału Konstytucyjnego ${ }^{29}$ restrykcyjne terminy względem pracowników wynikają z potrzeby zapewnienia pracodawcy możliwości przeorganizowania pracy i zapewnienia zastępstwa za pracownika, który ubiega się o urlop. Nie należy przy tym zapominać, że dwudziestojednodniowy termin dotyczy nie tylko procedury nabycia uprawnień urlopowych, lecz także uprawnień zasiłkowych. Jednak pracodawca, co do decyzji o udzieleniu urlopu, w przypadku niedochowania przez pracownika terminu nie zachowuje już takiej pełnej dowolności. W każdym razie dopóki pracodawca urlopu nie udzieli, dopóty pracownik-rodzic nie ma prawa urlopu rozpoczać. Prawo do urlopu to zdaniem A. Sobczyka ${ }^{30}$ prawo publiczne prywatne podmiotowe, a pracodawca musi w tym zakresie kierować się przede wszystkim wartością konstytucyjną, którą jest ochrona rodziny. Jakie zatem przepisy powinien stosować pracodawca w tym przypadku? Przepisy kodeksu postępowania administracyjnego ${ }^{31}$ są elastyczne i pozwalają rozstrzygać na korzyść uprawnionego, co idzie w parze z kodeksową zasadą korzystności. Jeżeli zatem pracodawca będzie w stanie (obiektywnie) przygotować się na nieobecność pracownika-rodzica i przeorganizować proces pracy oraz zapewnić zastępstwo, to mimo niezachowania terminu po stronie pracodawcy nie ma uzasadnienia nieuwzględnienia (odrzucenia) takiego spóźnionego wniosku. Z tym że jeżeli przeorganizowanie było obiektywnie możliwe, a mimo to pracodawca

27 Rozporządzenie Ministra Rodziny, Pracy i Polityki Społecznej z dnia 8 grudnia 2015 r. w sprawie wniosków dotyczących uprawnień pracowników związanych z rodzicielstwem oraz dokumentów dołączanych do takich wniosków (Dz.U.2015.2243).

28 A. Sobczyk, Komentarz do art. 179(1) k.p., [w:] Kodeks pracy. Komentarz, s. 197.

29 Wyrok Trybunału Konstytucyjnego z dnia 24 marca 2015 r., P 42/13, OTK-A 2015, nr 3, poz. 33 (Dz.U.2015/486).

30 A.Sobczyk, Komentarz do art. 182 (1d) k.p., [w:] Kodeks pracy. Komentarz, s. 740.

31 Ustawa z dnia 14 czerwca 1960 r. Kodeks postępowania administracyjnego (tekst jedn. Dz.U.2017.1257). 
odrzucił wniosek urlopowy pracownika, to wówczas ciężar udowodnienia spoczywać będzie wyłącznie na pracowniku ${ }^{32}$. Także gdy niedochowanie terminu było przez pracownika-rodzica działaniem niezawinionym, nie powinno powodować to utraty prawa do urlopu, jeżeli pracodawca miał możliwość rozpoznać wniosek do dnia rozpoczęcia korzystania z urlopu lub jego części. Zasadność stosowania przepisów kodeksu postępowania administracyjnego w zakresie nieuregulowanym w kodeksie pracy jest w opinii A. Sobczyka ${ }^{33}$ podparta również tym, że tam, gdzie prawo do urlopu związane jest z prawem do zasiłku, to pracodawca występuje de facto w pozycji analogicznej jak Zakład Ubezpieczeń Społecznych, czyli rozstrzyga o publicznym prawie podmiotowym (poza urlopem wychowawczym), a w analogicznym postępowaniu przed organem ubezpieczeniowym w przypadku ubezpieczonego niebędącego pracownikiem również stosuje się przepisy kodeksu postępowanie administracyjnego (art. $180 \S 1$ k.p.a.).

Kodeks pracy ani też rozporządzenie wykonawcze do art. 186 (8a) k.p. nie rozstrzygają o konsekwencjach dla pracownika-rodzica $\mathrm{w}$ razie niedochowania wymogów związanych z wnioskiem urlopowym, jak również nie dają pracodawcy żadnych wytycznych co do procedowania w tym zakresie. Jeżeli wniosek urlopowy nie spełnia wymogów merytorycznych, a dokumenty do niego dołączone nie są kompletne, to pracodawca do czasu uzupełnienia braków może wniosku nie uwzględniać. Pracodawca powinien, zgodnie z art. 64 ust. 2 k.p.a., wezwać pracownika do uzupełnienia braków wniosku urlopowego w terminie siedmiu dni pod rygorem pozostawienia wniosku bez rozpoznania. Problemy mogą zaistnieć, jeżeli pracownik-rodzic nie wypełni wezwania pracodawcy w zakreślonym terminie. Wówczas taki nieuwzględniony wniosek oznacza, iż pracownik nie nabył prawa do urlopu, a więc powinien zjawić się w pracy, inaczej jego nieobecność potraktowana będzie jako nieusprawiedliwiona. Oczywiście pracodawca ma prawo rozpatrzyć wniosek urlopowy pozytywnie mimo braków formalnych, jeżeli ma stosowną wiedzę z urzędu uzasadniającą prawo pracownika-rodzica do urlopu ${ }^{34}$.

Realizacja prawa pracownika do ochrony rodziny przez udzielenie urlopów rodzicielskich wykazuje - w opinii A. Sobczyka ${ }^{35}$ - znacznie więcej cech administracyjnych niż przy urlopach wypoczynkowych. Urlopy związanie z rodzicielstwem są przez pracodawcę ,udzielane” (pracodawca pozostaje obowiązany do udzielenia tego urlopu), a nie są przez pracownika „brane”. To z kolei sprawia, że prawo do urlopów związanych z rodzicielstwem w opinii autora nie może być traktowane jako uprawnienie umowne. Pracownik-rodzic ma prawo do urlopu, ale nie może z niego samodzielnie skorzystać, oprócz urlopu macierzyńskiego rozpoczynającego się z dniem porodu. Należy zauważyć, że pracodawca prowadzi klasyczne

32 A. Sobczyk, Komentarz do art. 179(1) k.p., s. 724.

33 A. Sobczyk, Komentarz do art. 180 k.p., [w:] Kodeks pracy. Komentarz, s. 732; idem, Komentarz do art. 182 (1d) k.p., s. 739.

34 A. Sobczyk, Komentarz do art. 182 (1e) k.p., [w:] Kodeks pracy. Komentarz, s. 741.

35 A. Sobczyk, Komentarz do art. 182 (1d) k.p., s. 739. 
postępowanie (administracyjne) wszczynane na wniosek uprawnionego (forma pisemna/odpowiednie wyprzedzenie), stosując względem wnioskodawcy indywidualny akt pracodawcy. Poza tym pracodawca musi dokonać rozstrzygnięcia, której z osób uprawnionych przysługuje urlop w danym stanie faktycznym (dlatego bada dokumentację drugiego uprawnionego, a wnioskodawca musi ją przedłożyć, badany jest wymiar urlopu oraz możliwość jego podziału na części). Gdy zostaną spełnione warunki formalne i merytoryczne wniosku, wówczas pracodawca ma obowiązek uwzględnić wniosek uprawnionego pracownika-rodzica.

Zważywszy na te rozważania, w pełni popieram poglądy o konieczności stosowania przepisów kodeksu postępowania administracyjnego w procedowaniu w zakresie wniosków urlopowych pracownika-rodzica, zarówno z powodu przychylności i korzystności rozstrzygnięć względem wnioskującego, jak i z powodu jasnych reguł dla pracodawcy. Stosowanie procedur administracyjnych uzasadnione pozostaje także dlatego, że pracodawca przy wypłacie zasiłku macierzyńskiego rozporządza środkami publicznymi, gdyż zasiłek macierzyński wypłacany jest właśnie ze środków publicznych, a zatem wykonuje akt władczy w zakresie realizacji funkcji ogólnospołecznych ${ }^{36}$. Pracodawca, udzielając urlopów związanych z uprawnieniami rodzicielskimi, jednocześnie przesądza o prawie do zasiłku dla uprawnionego rodzica i dokonuje jego wypłaty, a Zakład Ubezpieczeń Społecznych w pewnych przypadkach nie wydaje nawet decyzji w tym zakresie. Nie można jednak uznać, że w procesie tym ZUS zostaje zupełnie pominięty. Decyzja zasiłkowa musi być wydana, gdy pracodawca zatrudnia mniej niż dwadzieścia osób, natomiast w dużych zakładach pracy decyzje te wydaje (zastępuje) pracodawca aktem udzielenia urlopu. W mojej opinii samą okoliczność złożenia wniosku i przyznanie pracodawcy prawa do ,udzielenia" urlopu rodzicielskiego traktować należy wyłącznie jako wymóg formalny, porządkujący procedurę postępowania w tych sprawach. Nie należy też zapominać, że pracodawca nie ponosi ryzyka socjalnego związanego z macierzyństwem na takich zasadach jak przy urlopie chorobowym, co uznać należy za słuszne ${ }^{37}$.

W rozważaniach o roli pracodawcy w realizacji prawa do urlopów rodzicielskich należy pamiętać o wszelkich innych formach działań pracodawcy kształtujących sytuację prawną pracownika-rodzica, na przykład w zakresie wyrażenia przez pracodawcę zgody na rezygnację z urlopu rodzicielskiego czy też aprobaty odnośnie do możliwości łączenia urlopu rodzicielskiego z pracą u dotychczasowego pracodawcy (art. 182 (1e) k.p.). Zgodnie z przepisami kodeksu pracy ustawodawca przyznał pracownikowi korzystającemu z urlopu rodzicielskiego prawo do zrezygnowania $\mathrm{z}$ tego urlopu w każdym czasie, za zgodą pracodawcy, i powrót do pracy. Na pracowniku spoczywa formalny obowiązek złożenia wniosku — zgodnie a art. 186 (8a) pkt 3 k.p. — co oznacza, że pracownik ma nie tyle prawo do rezy-

36 A. Sobczyk, Komentarz do art. 184 k.p., [w:] Kodeks pracy. Komentarz, s. 753.
37 Ibidem. 
gnacji (kształtujące), ile jedynie prawo do złożenia wniosku o skrócenie urlopu lub jego częśsi ${ }^{38}$. Z kolei swoboda pracodawcy do nieuwzględnienia wniosku pracownika-rodzica zostaje ograniczona podstawową zasadą prawa do pracy (art. 10 k.p.), stąd też ewentualna odmowa pracodawcy winna zostać obiektywnie uzasadniona. Podobnie odnośnie do odmowy pracodawcy na łączenie pracy z urlopem rodzicielskim, która może być wyłącznie całkowita. W doktrynie wyrażany jest pogląd ${ }^{39}$, że bezzasadna odmowa zatrudnienia uzasadnia roszczenie o zadośćuczynienie oraz odszkodowanie ze względu na naruszenie wolności pracy jako dobra osobistego pracownika-rodzica oraz naruszenie jego prawa do opieki nad dzieckiem.

\section{C) PRACODAWCA JAKO GWARANT ZATRUDNIENIA PO WYKORZYSTANIU URLOPÓW RODZICIELSKICH PRZEZ PRACOWNIKA-RODZICA}

W myśl obowiązujących przepisów (art. $183^{2}$ k.p., art. 186 (4) k.p.) pracodawca pozostaje zobowiązany do zapewnienia zatrudnienia (powierzenia pracy, dopuszczenia do pracy) pracownikowi-rodzicowi powracającemu do pracy po zakończonym urlopie związanym z uprawnieniami rodzicielskimi. Regulacje te mają w swym ogólnym założeniu charakter gwarancyjny, co niewątpliwie zasługuje na aprobatę, ale nie oznacza, że nie są one problematyczne, czemu dano już wyraz niejednokrotnie w literaturze przedmiotu ${ }^{40}$.

W imię ochrony stabilności zatrudnienia ustawodawca w art. $183^{2}$ k.p. zezwala pracodawcy na podjęcie autonomicznej decyzji i dokonanie jednostronnej zmiany treści umowy o pracę bez konieczności stosowana wypowiedzenia zmieniającego ${ }^{41}$. Taka wykładnia jest powszechna, podparta orzecznictwem Sądu Najwyższego $^{42}$ i argumentem o konieczności dbania przez pracodawcę o dobro pracownika-rodzica. Tylko nie jest już takie pewne, czy w tej sytuacji dobro pracownicze jest wystarczająco chronione. Jak zauważa A. Sobczyk ${ }^{43}$, sytuacja pracownika zostaje znacząco osłabiona, jako że nie może on odmówić podjęcia zatrudnienia na nowym, nieuzgodnionym, stanowisku, albowiem gdyby nie był zainteresowany propozycją pracodawcy, jedyne co mu wówczas pozostaje, to wypowiedzieć umowę o pracę. Poza tym wyłacznie gdyby umowa o pracę nie określała stanowiska pracy, lecz tylko rodzaj pracy, to przepis miałby dla pracownika rzeczywiście charakter gwarancyjny ${ }^{44}$. Nie byłoby bowiem możliwe dokonywanie przesunięć pracownika na różne stanowiska pracy w ramach rodzaju pracy, co przy urlopach

38 A. Sobczyk, Komentarz do art. 182 (1d) k.p., s. 740

39 A. Sobczyk, Komentarz do art. 182 (1e) k.p., s. 741.

40 Zob. J. Czerniak-Swędzioł, Sytuacja prawna pracownika powracajacego do pracy po wykorzystaniu urlopów zwiąanych z rodzicielstwem - uwagi de lege ferenda, „Studia z Zakresu Prawa Pracy i Polityki Społecznej” 24, 2017, nr 2, s. 89-102.

41 A. Sobczyk, Prawo pracy w świetle Konstytucji RP, t. 2, s. 207.

42 Zob. wyrok SN z dnia 1 października 1984 r., I PRN 129/84, OSNCP 1985, nr 7, poz. 93.

43 A. Sobczyk, Komentarz do art. 183 (2) k.p., [w:] Kodeks pracy. Komentarz, s. 751.

44 A. Sobczyk, Prawo pracy w świetle Konstytucji RP, t. 2, s. 207-208. 
związanych z opieką nad dzieckiem jest przecież zasadniczo zabronione. Omawiany przepis nie zabrania pracodawcy dokonania wypowiedzenia zmieniającego lub wypowiedzenia definitywnego powracającemu pracownikowi-rodzicowi, ale dopóki pracodawca ma alternatywne możliwości zatrudnienia takiego pracownika zgodnie z jego kwalifikacjami, nie będzie to możliwe do zrealizowania.

Zgodnie z poglądem wyrażonym przez Sąd Najwyższy ${ }^{45}$, który poddać należy zdecydowanej krytyce, pracodawca nie może odmówić zatrudnienia pracownicy po urlopie wychowawczym, nawet gdy nie dysponuje stanowiskiem dotychczasowym, równorzędnym lub odpowiadającym jej kwalifikacjom. Zdaniem SN dopuszczenie do pracy stanowi bezwzględny obowiązek pracodawcy, ale nie oznacza, że nie można wypowiedzieć umowy o pracę po powrocie z urlopu wychowawczego. Pozbawione jakiegokolwiek sensu jest uznanie, że zarówno art. $183^{2}$ k.p., jak i art. 186 (4) k.p. służą temu, aby jedynie dopuścić pracownika-rodzica do pracy, a następnie go zwolnić. Ratio legis tych regulacji sprowadza się do zapewnienia takiemu pracownikowi zatrudnienia po wykorzystaniu urlopu związanego z rodzicielstwem. Przy czym zapewnienie zatrudnienia w imię ochrony praw pracownika-rodzica nie powinno sprowadzać się do zapewnienia jakiejkolwiek pracy i nie powinno odbywać się kosztem całkowitego ograniczenia wolności gospodarczych pracodawcy.

D) SYTUACJA PRAWNA PRACOWNIKA-RODZICA W OKRESIE SPRAWOWANIA OPIEKI NAD DZIECKIEM A ROLA PRACODAWCY

Rozwiązania kodeksu pracy chroniące pracownika-rodzica w okresie sprawowania opieki nad dzieckiem są wynikiem propagowanego przez Unię Europejską rozwiązania mającego służyć godzeniu życia zawodowego i prywatnego pracownika-rodzica przez umiejętne godzenie pracy zawodowej z osobistą opieką na dzieckiem ${ }^{46}$. W związku z tym pracownik-rodzic, któremu przysługuje uprawnienie do urlopu wychowawczego, może żądać od pracodawcy obniżenia wymiaru etatu w okresie sprawowania opieki nad dzieckiem, a to zgodnie $z$ art. 186 (7) k.p. ${ }^{47}$ Pracodawca, tak jak przy urlopach rodzicielskich, ma obowiązek uwzględnić wniosek pracownika. Mając na względzie brzmienie komentowanego przepisu, należy jednak zauważyć, że pracownik może wnioskować o obniżenie wymiaru etatu, ale już nie o modyfikację rozkładu czasu pracy. Wniosek pracownika-rodzica w tym ostatnim zakresie nie jest dla pracodawcy wiążący, choć nie ma przeszkód, aby

45 Zob. uzasadnienie uchwały SN z dnia 30 grudnia 1985 r., III PZP 50/85, OSNCP 1986, nr 7-8, poz. 118.

46 Por. L. Mitrus, Ochrona rodzicielstwa w świetle zmian Kodeksu pracy, [w:] Jedność w różnorodności. Studia z zakresu prawa pracy, zabezpieczenia społecznego i polityki społecznej. Księga pamiatkowa dedykowana Profesorowi Wojciechowi Muszalskiemu, red. A. Patulski, K. Walczak, Warszawa 2009, s. $192 \mathrm{n}$.

47 P. Sołtys, Problematyka prawna obniżenia wymiaru etatu przez pracownika-rodzica wychowujacego dziecko, „Studia z Zakresu Prawa Pracy i Polityki Społecznej” 21, 2014, s. 85 n. 
został uwzględniony zgodnie z oczekiwaniami pracownika. Wówczas na mocy swoistego porozumienia stron dojdzie do ustalenia indywidualnego rozkładu czasu pracy oraz obniżenia wymiaru etatu. Tak więc efektywne korzystanie z obniżonego wymiaru czasu pracy wymaga porozumienia stron stosunku pracy, zwłaszcza że pracodawca może zupełnie legalnie wykonać swój ustawowy obowiązek, który z perspektywy opieki nad dzieckiem może okazać się zupełnie dysfunkcjonalny ${ }^{48}$. Zasadnicze pytanie, jakie tu się pojawia, dotyczy pracodawcy: czy będąc związany wnioskiem pracownika-rodzica, może odmówić mu udzielenia obniżenia wymiaru etatu? Jeżeli wniosek pracownika służy realizacji celu, jakim jest sprawowanie osobistej opieki nad dzieckiem ${ }^{49}$, to odmowa pracodawcy jako nieuzasadniona doprowadzi do naruszenia konstytucyjnych praw pracownika-rodzica. Jeśli jednak pracownik w czasie składania wniosku prowadzi inną aktywność zawodową lub społeczną, która dowodzi, że obniżenie etatu nie służy jego celowi, to pracodawca ma prawo odmówić obniżenia etatu lub stwierdzić wygaśnięcie tego prawa ${ }^{50}$. Podzielam zapatrywanie, że przyczyną, dla której pracodawca może odmówić uwzględnienia wniosku, będzie również symboliczne wnioskowanie o obniżenie wymiaru służące jedynie pozyskaniu stosownej ochrony — na gruncie art. 186 (8) $\S 1$ k.p. - przez pracownika-rodzica ${ }^{51}$. Taki wniosek nie będzie dla pracodawcy wiążący i należy potraktować go jako nadużycie prawa z powodu niemożności racjonalnego wykonywania obowiązku opieki nad dzieckiem. Pracodawca, jako że realnie wpływa na sposób wykonywania tego ustawowego obowiązku przez pracownika-rodzica, ma pełne prawo oczekiwać współpracy z pracownikiem w tym zakresie, aby każdy przypadek ocenić indywidualnie względem konkretnej sytuacji życiowej danego pracownika.

Dokonując zatem całościowej oceny tych rozwiązań z pozycji samego podmiotu zatrudniającego, wskazać należy, że kolejny raz mamy do czynienia z regulacją zdecydowanie naruszającą zasadę proporcjonalności ingerencji w swobodę działalności gospodarczej pracodawcy. Idea okresowego obniżenia wymiaru etatu w okresie opieki nad dzieckiem zasługuje na aprobatę, ale jednostronne uprzywilejowanie pracownika kosztem pracodawcy zostało już, zresztą bardzo słusznie, poddane krytyce przez przedstawicieli doktryny ${ }^{52}$. Rola pracodawcy, już po raz kolejny, przy realizacji uprawnień pracowniczych związanych z rodzicielstwem ograniczona zostaje do minimum. W istocie brakuje jakichkolwiek regulacji kodeksowych

48 A. Sobczyk, Komentarz do art. 186 (7) k.p., [w:] Kodeks pracy. Komentarz, s. 762.

49 Osobista opieka nad dzieckiem nie oznacza konieczności przebywania z nim stale, jak też tego, że nie można skorzystać z pomocy innych członków rodziny czy odpowiednich placówek (żłobek, przedszkole, klub dziecięcy) niezależnie od liczby godzin pobytu dziecka w tych placówkach, jeśli nie nastąpiło trwałe zaprzestanie sprawowania opieki przez rodzica. Por. wyrok NSA z dnia 25 marca 2011 r., I OSK 2066/10, LEX nr 1079748.

50 A. Sobczyk, Komentarz do art. 186 (7) k.p., s. 763.

51 Zob. Ł. Pisarczyk, Zmniejszenie wymiaru czasu pracy — odpowiedź na potrzeby pracowników i kryzys przedsiębiorstwa, PiZS 2010, nr 6, s. 2 n.

52 A. Sobczyk, Prawo pracy w'świetle Konstytucji, t. 2, s. 206-212. 
stabilizujących sytuację gospodarczą pracodawcy i uwzględniających jego interesy. Pracodawca wystawiony jest wyłącznie na decyzje pracownika i w zasadzie nie ma realnej możliwości weryfikacji jego sytuacji. W perspektywie omawianego przepisu nie została w ogóle uwzględniona sytuacja małych pracodawców, dla których taka niestabilność godzić może w bezpieczeństwo prowadzenia racjonalnej działalności gospodarczej oraz generuje wysokie koszty, związane choćby z zastępstwem za część pracy. Poza tym praca w obniżonym wymiarze jest często pozbawiona ekonomicznego sensu, szczególnie na wysokich jednoosobowych stanowiskach (dyrektorskich, menedżerskich), odnośnie do których obniżenie wymiaru etatu może być trudne w realizacji, a nawet sparaliżować wykonywanie pracy właśnie z powodu jej charakteru. Również wynagrodzenie za taką pracę zostaje oderwane od wartości świadczenia wzajemnego i staje się wsparciem socjalnym pracownika-rodzica. Widoczna jest tu mechaniczna ochrona pracownika-rodzica, nie odnosi się bowiem ona do przyczyn związanych z rodzicielstwem.

\section{OBOWIĄZKI PRACODAWCY W PRZEDMIOCIE ORGANIZACJI PROCESU PRACY PRACOWNIKA-RODZICA}

Obciążenie pracodawcy konsekwencjami zmian w organizacji procesu pracy, a w pewnym zakresie też ryzykiem płacowym, jest przejawem zaangażowania podmiotu zatrudniającego $\mathrm{w}$ realizację istotnych celów społecznych, związanych z ochroną życia i zdrowia pracownika, rodziny i macierzyństwa. Zdaniem Ł. Pisarczyka $^{53}$ ich osiągnięcie bez udziału pracodawcy nie byłoby możliwe, dotyczy to zwłaszcza przerwania procesu pracy przy jednoczesnym utrzymaniu więzi prawnej istniejącej między stronami stosunku pracy. Obowiązki pracodawcy związane z koniecznością zmiany organizacji procesu pracy pracownika-rodzica można podzielić na dwie grupy, to znaczy te związane z dostosowaniem warunków pracy dla kobiety w ciąży oraz kobiety karmiącej i te odnoszące się do modyfikacji dotychczasowych warunków pracy ze względu na sprawowanie przez pracownika obowiązków rodzica.

Polski pracodawca, zgodnie z art. 176 k.p. ${ }^{54}$, ma prawo zawrzeć umowę o pracę z pracownicą w ciąży lub karmiącą, nawet jeżeli dotyczy to prac wzbronionych tej grupie kobiet, ale już nie będzie mógł dopuścić do wykonywania takiej pracy, jeśli wie o stanie pracownicy. Inaczej jest, jeśli pracodawca nie wie o sta-

53 Ł. Pisarczyk, Ryzyko pracodawcy, Warszawa 2008, s. 257.

$54 \mathrm{~W}$ przepisach dotyczących ochrony pracy kobiet występują obok siebie dwa pojęcia związane z ograniczeniami dla pracodawcy w możliwości świadczenia pracy przez kobietę w ciąży. Mianowicie w art. 176 k.p. mowa jest o niedopuszczalności wykonywania pracy, natomiast w art. 178 k.p. oraz art. $178^{1}$ k.p. ustawodawca używa określenia o niemożliwości zatrudnienia. Słuszną metodę interpretacji tych przepisów w tym zakresie przeprowadził A. Sobczyk, [w:] Kodeks pracy. Komentarz, s. 716. 
nie kobiety - wówczas ma prawo zażądać ujawnienia takich informacji, o ile uzasadni, że jego zamiarem jest zatrudnienie przy takich pracach. Pogląd taki można wyprowadzić a contrario z tezy orzeczenia Sądu Najwyższego ${ }^{55}$, uznającego, że kobieta nie ma obowiązku udzielać informacji o fakcie pozostawania w ciąży, jeżeli praca, jaką zamierza podjąć, nie jest zabroniona (niedozwolona) ze względu na ochronę macierzyństwa. Skoro prawo nie zabrania zatrudniania kobiety w ciąży, a odmowa zatrudnienia tylko z powodu ciąży byłaby uznana za dyskryminację $e^{56}$, to w zasadzie pracodawca zostaje przymuszony do zatrudnienia. Jednak z powodu niemożności dopuszczenia kobiety w ciąży/karmiącej do umówionej pracy, musi zapewnić jej inną pracę albo zwolnić ją z obowiązku świadczenia tej pracy (art. 179 k.p.), co generuje wysokie koszty. Ewentualnie może odmówić zatrudnienia z powodu stanu pracownicy i narazić się na zarzut działania dyskryminującego. Z tym że jeżeli pracodawca miałby zatrudnić tylko po to, aby następnie zwolnić pracownicę z obowiązku świadczenia pracy i wypłacać za ten czas wynagrodzenie, doszłoby do naruszenia konstytucyjnej zasady proporcjonalności obciążeń, a pracodawca stałby się zakładnikiem własnych decyzji. Toteż podzielam pogląd, że w pewnych przypadkach pracodawca może odmówić zatrudnienia kobiety w ciąży/karmiącej, jeżeli wie o takim stanie, koszty zaś, jakie musiałby ponieść w związku z zapewnieniem innej pracy lub zwolnieniem $\mathrm{z}$ obowiązku jej świadczenia, byłyby istotne, a odmowa taka nie będzie dyskryminacją ${ }^{57}$. Analogicznie jest $\mathrm{z}$ pracownicą w ciąży zatrudnioną w porze nocnej (art. $178^{1}$ k.p.). Także w tym przypadku, jeżeli dokonanie zmian w rozkładzie czasu pracy lub stanowiska pracy jest niemożliwe lub niecelowe, pracodawca pozostaje zobowiązany do zwolnienia pracownicy ze świadczenia pracy przy całkowitym pominięciu jego wielkości i siły ekonomicznej.

Jak wynika z przedstawionej analizy, polski ustawodawca przewidział dość istotne ograniczenia $\mathrm{w}$ organizowaniu procesu pracy kobiety w ciąży oraz kobiety karmiącej, włącznie ze zwolnieniem z obowiązku świadczenia pracy. Zasadą pozostaje wówczas ponoszenie przez pracodawcę pełnego ryzyka płacowego, co stanowi efekt wliczania przerw do czasu pracy lub zagwarantowania takiej pracownicy za czas zwolnienia od pracy wynagrodzenia obliczanego jak ekwiwalent za urlop wypoczynkowy ${ }^{58}$. To pełne ryzyko placowe pracodawcy uzasadnia się oczywiście sytuacją życiową takiej pracownicy oraz ochroną wartości wyższych. Pojawia się tylko pytanie, czy rozwiązanie przyjęte w kodeksie pracy jest słuszne i czy nie prowadzi do stosowania przez pracodawców niedopuszczalnych praktyk selekcyjnych względem tej grupy kobiet. Odpowiedź wydaje się oczywista, szczególnie w konfrontacji z rozwiązaniami przyjętymi w prawie międzynarodowym. Odejście od indywidualnego obciążenia pracodawcy ryzykiem płacowym to za-

55 Wyrok SN z dnia 17 kwietnia 2007 r., I UK 324/06, M.P.Pr 2007, nr 12, poz. 654.

56 Wyrok SN z dnia 11 stycznia 2006 r., II UK 51/05, OSNP 2006, nr 23-24, poz. 366.

57 A. Sobczyk, [w:] Kodeks pracy. Komentarz, s. 711.

58 Ł. Pisarczyk, Ryzyko pracodawcy, s. 261. 
sada wyrażona w art. 6 ust. 8 Konwencji MOP nr 183, przewidująca tworzenie obowiązkowego systemu ubezpieczeń i funduszy publicznych przeznaczonych właśnie na ten cel. Do zasadniczego zwolnienia pracodawcy z ryzyka płacowego związanego z uprawnieniami rodzicielskimi doszło we wszystkich krajach członkowskich Wspólnoty Europejskiej ${ }^{59}$.

Bez wątpienia prawo pracy w wysokim stopniu uwzględnia interesy pracowników-rodziców, ale w równie nie mniejszym interesy socjalne oraz zdrowie dziecka. W związku z tym na pracodawcy spoczywa wiele obowiązków organizacyjnych $\mathrm{w}$ zakresie dostosowania czasu pracy pracownika-rodzica właśnie z powodu potrzeb jego dziecka ${ }^{60}$. Jako przykład wskazać można art. 178 § 2 k.p. oraz art. 148 pkt 3 k.p., mówiące o obowiązku pozyskania przez pracodawcę zgody od pracownika opiekującego się dzieckiem do ukończenia przez nie czwartego roku życia w kwestii zatrudnienia takiego pracownika między innymi w godzinach nadliczbowych czy porze nocnej. Przykładem kolejnej regulacji obciążającej pracodawcę jest konieczność zapewnienia pracownicy przerw związanych z karmieniem dziecka (art. 187 k.p.) przy jednoczesnym utrzymaniu obowiązku wypłaty wynagrodzenia za czas takiej przerwy, która wliczana jest do czasu pracy. Pracodawca ma obowiązek udzielania odpłatnych zwolnień z pracy związanych z opieką nad dzieckiem włącznie z opieką nad dzieckiem zdrowym (art. 188 k.p.). Regulacje te ukazują znaczne ograniczenie uprawnień pracodawcy jako organizatora procesu pracy z powodu ochrony pracowników-rodziców przed nakładaniem na nich obowiązków, które mogłyby kolidować z wykonywaniem istotnej roli społecznej, jaką jest bycie rodzicem.

Prawo pracy chroni także interesy innych członków rodziny pracownika, co wyraża się w przepisach dotyczących zwolnień od pracy. Obowiązki pracodawcy mają wówczas przede wszystkim charakter organizacyjny, nakazujący udzielanie w sytuacjach koniecznych czasu wolnego oraz zakazujący wyciągania z powodu takich nieobecności negatywnych konsekwencji wobec pracownika ${ }^{61}$.

\section{UWAGI KOŃCOWE}

Przeprowadzona analiza $\mathrm{w}$ temacie roli pracodawcy w realizowaniu uprawnień pracowników związanych z rodzicielstwem skłania niestety do krytycznych refleksji. W obecnym kształcie przepisów kodeksu pracy podmiot zatrudniający pozostaje zbyt obciążony na rzecz ochrony szeroko rozumianego rodzicielstwa

59 Ibidem.

60 Zob. L. Latos-Miłkowska, Godzenie pracy zawodowej z życiem rodzinnym w przepisach o czasie pracy, PiZS 2008, nr 7, s. 8 n.

61 A. Sobczyk, Prawo pracy w świetle konstytucji, t. 1. Teoria publicznego i prywatnego indywidualnego prawa pracy, Warszawa 2013, s. 228-229. 
pracownika. Obciążenia związane są przede wszystkim z polityką społeczną, a pracodawca występuje w roli jedynego wykonawcy obowiązków społecznych związanych z ochroną życia i zdrowia pracownika, macierzyństwa, rodzicielstwa i rodziny, pozostając zobowiązany, a nawet i przymuszony do zatrudnienia socjalnego takiego pracownika-rodzica. Spoczywające aktualnie na pracodawcy obciążenia wynikające z przepisów kodeksu pracy mogłyby być realizowane w znacznym stopniu przez odpowiednie publiczne systemy ubezpieczeniowe. De lege ferenda obowiązek ochrony macierzyństwa oraz rodziny jako konstytucyjny obowiązek społeczny winien być realizowany wspólnie przez państwo i pracodawcę, ale przy zachowaniu odpowiednich proporcji obciążenia w jego wykonaniu oraz przy uwzględnieniu możliwości ekonomicznych i wielkości konkretnego podmiotu zatrudniającego. De lege lata wyraźnie widoczna w obowiązujących przepisach nieproporcjonalność znacząco ogranicza zasadę wolności gospodarczej oraz własności pracodawcy, w szczególności w stosunku do małych przedsiębiorców. Egzekwowana dość wyraźnie przez ustawodawcę gwarancja w zapewnieniu stabilności zatrudnienia dla pracownika-rodzica uderza bezpośrednio w kondycję finansową oraz osobistą każdego pracodawcy, ale szczególnie mocno dotyka mikropracodawców. Nie uważam przy tym, aby pozostawiać pracodawcę bezkarnym w sytuacji naruszenia zasady ochrony pracy z powodu rodzicielstwa, ale stawiając wniosek de lege lata, za słuszne uznaję sankcjonowanie tych naruszeń na gruncie przepisów prawa cywilnego, a nie przymusem zatrudnienia stanowiącym zaprzeczenie zasady dobrowolności. Również bezwzględna ochrona kobiety w ciąży nie prowadzi do niczego dobrego. Czyni prawo nieskutecznym, wręcz zniechęca do zatrudniania kobiet, co zdecydowanie pogarsza ich sytuację na i tak trudnym rynku pracy. Toteż o wiele lepszym rozwiązaniem byłoby wzmocnienie systemu świadczeń ubezpieczeniowych przyznawanych takim kobietom na okoliczność utraty przez nie zatrudnienia. Ponadto, już sam fakt, że krajowe rozwiązania odnoszące się do sytuacji i roli pracodawcy względem obowiązku ochrony pracownika-rodzica ewidentnie odstają do regulacji międzynarodowych, powinien skłonić nie tylko do refleksji, lecz przede wszystkim do podjęcia konkretnych działań w zakresie zmian w obowiązujących regulacjach prawnych.

\section{THE ROLE OF THE EMPLOYER IN REALIZING THE RIGHTS OF EMPLOYEES RELATED TO PARENTHOOD}

\section{Summary}

Over the last ten years, the Labor Code has significantly expanded employees' rights related to parenthood, and thus the role of the employer in the field of their implementation has changed fundamentally.

The employer remains obliged to fulfill the employee's basic rights enumerated in the Labour Code as a parent. However, the Polish legislator excessively burdens the employer with the role of 
the sole contractor of these general social principles related to the protection of motherhood and family, which causes a clear upset in the implementation of the constitutional obligations of the state towards its citizens.

Looking at individual stages of employment from the period of pregnancy, in which protection is particularly strong, through the obligation to exercise parental leave and obligations imposed on the employer to employ an employee after taking leave, on protection during the period of custody, these are clearly noticeable limitations and burdens for the employer. The burden imposed on a particular employer often remains completely disproportionate to its capabilities. The employer bears the costs of social policy, which should be implemented by the state, thus it is fulfilling the role of the guarantor in securing social interests. The solutions adopted by the Polish legislator stand in clear opposition to the regulation of international law.

The burdens currently imposed on the employer resulting from the provisions of the Labor Code could be implemented to a large extent by relevant public insurance systems. De lege ferenda, the obligation to protect motherhood and the family as a constitutional social obligation should be carried out jointly by the state and the employer. De lege lata, the lack of proportionality is clearly visible in the regulations in force and it significantly limits the principle of economic freedom and employer's property, in particular in relation to small entrepreneurs.

Keywords: employer, parental rights

\section{BIBLIOGRAFIA}

Czerniak-Swędzioł J., Ewolucja urlopu rodzicielskiego, „Studia z Zakresu Prawa Pracy i Polityki Społecznej” 23, 2016.

Czerniak-Swędzioł J., Sytuacja prawna pracownika powracającego do pracy po wykorzystaniu urlopów zwiazanych z rodzicielstwem - uwagi de lege ferenda, „Studia z Zakresu Prawa Pracy i Polityki Społecznej” 24, 2017, nr 2.

Czerniak-Swędzioł J., Uwagi de lege lata $i$ de lege ferenda $w$ przedmiocie umowy o prace na zastępstwo, „Studia z Zakresu Prawa Pracy i Polityki Społecznej” 22, 2015.

Czerniak-Swędzioł J., Zakres uprawnień związanych z rodzicielstwem w przypadku zatrudnienia na podstawie terminowej umowy o prace, [w:] Terminowe umowy o pracę red. M. Mędrala, Warszawa 2017.

Dörre-Kolasa D., Komentarz do art. 94 k.p., [w:] Kodeks pracy. Komentarz, red. A. Sobczyk, Warszawa 2017

Jackowiak U., Sytuacja pracownicza kobiet, Gdańsk 1994.

Latos-Miłkowska L., Godzenie pracy zawodowej z życiem rodzinnym w przepisach o czasie pracy, PiZS 2008, nr 7.

Liszcz T., Ochrona pracy kobiet i pracowników wychowujacych dzieci - propozycje zmian, PiZS 1989, z 1 .

Mitrus L., Ochrona rodzicielstwa w świetle zmian Kodeksu pracy, [w:] Jedność w różnorodności. Studia z zakresu prawa pracy, zabezpieczenia społecznego i polityki społecznej. Ksiega pamiątkowa dedykowana Profesorowi Wojciechowi Muszalskiemu, red. A. Patulski, K. Walczak, Warszawa 2009.

Pisarczyk Ł., Ryzyko pracodawcy, Warszawa 2008.

Pisarczyk Ł., Zmniejszenie wymiaru czasu pracy — odpowiedź na potrzeby pracowników i kryzys przedsiębiorstwa, PiZS 2010, nr 6.

Sobczyk A. (red.) D. Dorre-Kolasa, M. Gładoch, P. Korus, L. Mitrus, A. Sobczyk, J. Stelina, M. Zieleniecki, Kodeks pracy. Komentarz, Warszawa 2017. 
Sobczyk A., [w:] Kodeks pracy. Komentarz, red. A. Sobczyk, Warszawa ${ }^{3} 2017$.

Sobczyk A., Prawo pracy w świetle Konstytucji RP, t. 1. Teoria publicznego i prywatnego indywidualnego prawa pracy, Warszawa 2013.

Sobczyk A., Prawo pracy w świetle Konstytucji RP, t. 2. Wybrane problemy i instytucje prawa pracy a ochrona konstytucyjnych praw $i$ wolności człowieka, Warszawa 2013.

Sołtys P., Problematyka prawna obniżenia wymiaru etatu przez pracownika-rodzica wychowujacego dziecko, „Studia z Zakresu Prawa Pracy i Polityki Społecznej” 21, 2014.

Stecko S., Konstytucyjna zasada ochrony macierzyństwa i rodzicielstwa oraz wynikajace z niej uprawnienia kobiet-pracownic w związu z urodzeniem dziecka, „Przegląd Prawa Publicznego" 2017, nr 5. 